\title{
Teacher absence as a factor in gender inequalities in access to primary schooling in rural Pakistan
}

\author{
Sharon Ghuman \\ Population Council \\ Cynthia B. Lloyd \\ Population Council
}

Follow this and additional works at: https://knowledgecommons.popcouncil.org/departments_sbsr-pgy

Part of the Demography, Population, and Ecology Commons, Family, Life Course, and Society Commons, Gender Equity in Education Commons, International Public Health Commons, and the Rural Sociology Commons How does access to this work benefit you? Let us know!

\section{Recommended Citation}

Ghuman, Sharon and Cynthia B. Lloyd. 2007. "Teacher absence as a factor in gender inequalities in access to primary schooling in rural Pakistan," Poverty, Gender, and Youth Working Paper no. 1. New York: Population Council. 


\section{POVERTY, GENDER, AND YOUTH}

Teacher Absence as a Factor in Gender Inequalities in Access to Primary Schooling in Rural Pakistan

Sharon Ghuman and Cynthia B. Lloyd 


\section{(2) Population Council}

One Dag Hammarskjold Plaza

New York, New York 10017 USA

www.popcouncil.org pubinfo@popcouncil.org

Our new name Beginning with the first number of 2007, Policy Research Division working papers are now called Poverty, Gender, and Youth working papers. For information on papers in both series, including those that are available for downloading in PDF format, see www.popcouncil.org/publications/wp/index.html

This material may not be reproduced without written permission from the authors.

This 15 June 2007 posting replaces the posting of this publication in May 2007. On page 19, Table 1, the heading for the last three rows has been revised from "Type of government school" to "De jure status."

ISSN: $1554-8538$

(C) 2007 The Population Council, Inc. 


\section{Teacher Absence as a Factor in Gender Inequalities in Access to Primary Schooling in Rural Pakistan}

Sharon Ghuman

Cynthia B. Lloyd

Sharon Ghuman is Resident Fellow and Cynthia B. Lloyd is Senior Associate, Population Council, New York.

The Spencer Foundation, the Department for International Development, UK, and the William and Flora Hewlett Foundation provided financial support for this research. An earlier version of this paper was presented at the seminar on "Gender and Access in South Asia," organized by the International Union for the Scientific Study of Population and the Bangladesh Institute for Development Studies, and at the Quantitative Methods in Social Sciences seminar series at Columbia University. We thank the seminar participants as well as Sajeda Amin, Nazmul Chaudhury, Minhaj ul Haque (local project director of the study), and Barbara Miller for helpful input. 


\begin{abstract}
Public-sector education in many countries in western and southern Asia, including Pakistan, is characterized by separate schools for boys and girls at the primary and secondary levels. We examine the case of Pakistan, where primary school enrollment among girls in rural areas is substantially lower than among children in urban areas and boys in rural areas, owing to lack of access to government girls' schools. Our focus is on teacher absence as a further barrier to schooling for girls. Absence rates among the allfemale teachers in government girls' schools are substantially higher than among the allmale teachers in government boys' schools. In 1997, about 35 percent of teachers in government girls' schools and 22 percent of teachers in government boys' schools in our sample from Northwest Frontier Province and Punjab were absent during unannounced visits to schools. About 25 percent of enrolled girls and 17 percent of enrolled boys in government schools did not have a teacher present to teach their class. By 2004, the percentage of enrolled children without a teacher was lower because of reduced absences of teachers in both Punjab and NWFP, but the gender gap remained. Whether they teach in government or private schools, women who live in the same community as the school are substantially less likely to be absent. In government girls' schools, better basic amenities are also related to lower teacher absence. Both findings suggest the importance of recent government investments in schools and the higher inter-village travel costs faced by women relative to men.
\end{abstract}


A growing number of studies have shown that provider absence is an important obstacle in the provision of education and health care services in many low- and middleincome countries. ${ }^{1}$ A study of six countries in which primary schools were randomly visited two or three times between 2002 and 2003 found that 11 to 27 percent of primary school teachers were absent on the day of the visit ${ }^{2}$ (Chaudhury et al. 2006). A study of four states in India found that one third of head teachers were absent at the time of the school visit, and any teaching-related activity was found in only half of all schools visited (Public Report on Basic Education in India-PROBE 1999). The presence of a teacher in the classroom is a central aspect of education and a necessary condition for student learning.

Separate government schools for boys and girls are found in many Islamic countries, such as Afghanistan, Bahrain, Iran, Jordan, Kuwait, Libya, Oman, Qatar, Saudi Arabia, and the United Arab Emirates (Al-Nayadi 1994; Brewer et al. 2006; Browne 2002; Battle-Walters 2002; Hamdan 2005; Lesko 2002a, 2002b; Mehran 2003; Obeidat 2002; World Bank 2005c). In Afghanistan and Iran teachers are also the same sex as students. With the exception of Afghanistan, these countries differ from Pakistan in two key respects: they have substantially higher per capita national income levels and a longer tradition of committing a substantial share of national resources to education. These factors have contributed to effectively maintaining expensive separate schooling systems for each sex. It is noteworthy that net primary school enrollment rates in these Islamic countries are generally higher than (or on par with) rates in Pakistan and do not differ by sex (World Bank n.d.). Although these countries share with Pakistan problems related to a shortage of teachers (a sizable fraction of whom are often women), they have partially alleviated teacher shortages by employing teachers from abroad or investing in teacher training programs domestically to draw on relatively well-educated female populations.

Here we examine the case of Pakistan-also a country with single-sex education, same-sex teachers, and a shortage of women to teach girls - but one that has underperformed in primary school enrollment, especially among girls in rural areas. Our interest is in the availability of teachers, as measured by teacher absence, and its implications for differential access to schooling by sex in rural areas. Despite sustained economic growth since the 1950 s, the net enrollment rate in primary school in Pakistan in 2004 was 66 percent, lower than the South Asia average of 87 percent and lower than for countries at similar income levels (Easterly 2003; World Bank n.d.). Pakistan's large gender gap in enrollment exceeds that observed in many neighboring countries: among children aged 10-14, about 40 percent of girls never enrolled in school compared to 20 percent of boys (Lloyd 2004). This gender gap, largely a rural phenomenon, is attributed to a historically low level of government investment in human development that is slowly beginning to change.

In coeducational settings, absence by teachers is unlikely to have different implications for the share of enrolled boys or girls who miss out on education. In Pakistan, however, teacher absence is markedly higher in government girls' schools, which are staffed exclusively by women, than in government boys' schools, staffed exclusively by men. A 2004 survey of primary schools in rural Pakistan showed that 14 percent of male teachers and 32 percent of female teachers were absent (World Bank 2002b). If we consider 
school access to be determined not only by the physical proximity of schools according to school type (i.e., government girls', government boys', or private coed schools) but also by other "barriers to use" (e.g., whether schools offer all five primary classes) according to school type, then teacher absence from the school creates additional "barriers to use." Thus, in Pakistan, sex-segregated schools with same-sex teachers appear to place girls at a particular disadvantage. Girls' schools are far from universally available in rural areas, and the patterns of teacher absence observed in the government sector exacerbate existing gender inequalities in access to schooling for children enrolled in these schools.

The 1990s saw a rapid rise in the formation of coeducational and low-fee private schools in rural areas, particularly in Punjab and Northwest Frontier Province (NWFP) (Andrabi, Das, and Khwaja 2002, 2006a, 2006b). These schools are secular. ${ }^{3}$ About 20 percent of enrolled children aged 5 to 10 attend private schools, and teacher absences in these schools are about one third (among men) and one half (among women) of the levels in government schools (Andrabi, Das, and Khwaja 2006b). Other changes include substantial improvements in the working conditions in government girls' schools as a result of upgrading of basic infrastructure.

Using data from a panel study of primary schooling in rural Punjab and NWFP in 1997 and 2004, we examine teacher absence in the government and private sector. We show trends in teacher absence, examine the factors correlated with teacher absence in the government and private sector, and assess the implications of these absence levels for access to schooling among enrolled boys and girls.

\section{The Pakistan Context}

Evidence suggests that constraints in access to government schools as measured by distance to or the presence of a school in a community are key factors in the decision of parents to enroll their children, particularly girls (see Lloyd, Mete, and Sathar 2005 for a review). The available number of government primary schools for girls has risen perceptibly since the early 1990s, although by 2001 about one third of communities in rural Pakistan still had no government primary school for girls compared to 15 percent for boys (World Bank 2005a). ${ }^{4}$

Teacher absence is common in government schools in Punjab and NWFP, but we know little about what characteristics of teachers and schools are associated with absence. In 2001, 10 percent of teachers in primary schools in NWFP and 25 percent in Punjab were absent on a given day (World Bank 2002b). High absence levels among government compared to private school teachers may at first appear puzzling since the former are better trained, have more experience, and command much higher pay. In our sample, all but 6

percent of government school teachers have some form of teacher training ${ }^{5}$ (compared to 32 percent among private school teachers) and have been teaching for about 14 years on average (compared to about 4 years for private school teachers). Nevertheless, previous research shows that years teaching at a school, teachers' level of education, and teachers' training are not associated with lower absence of teachers across several countries (Chaudhury et al. 2006). Indeed, factors such as being male or a head teacher, which reflect 
higher salary and seniority, were consistently related to higher absence, probably because they confer power and protection from any monitoring systems in place (Chaudhury et al. 2004, 2006; Kremer et al. 2005). ${ }^{6}$

Low teacher accountability is a major problem in government schools. The assignment of teaching posts is often based on political connections (Hasnain 2005), and, once hired, firing teachers is difficult. There is no comprehensive system to monitor teacher absence in Punjab and NWFP. Recent pilot initiatives that have encouraged hiring of teachers by the school rather than at the district level have apparently been successful in reducing absence in NWFP (World Bank 2005b). The poor state of government schools, especially for girls, that prevailed until recently is also likely to influence teacher incentives and effort. Conditions in girls' schools have improved since the mid-1990s as the result of government investments in basic amenities as part of its Social Action Program. The program was adopted in the early 1990s to improve basic services related to health, education, and other infrastructure, and subsequent education-sector reforms were developed in an effort to improve quality (World Bank 2002a). In our 1997 data, for example, the percentage of government schools that had electricity, toilets, and desks was 0 for girls' schools and 4.5 for boys' schools. By 2004, the percentage with all these amenities was 26 for girls' schools and 21 for boys' schools, indicating substantial changes particularly for girls' schools. In 1997 and 2004, 83 and 92 percent of private schools had all of these amenities.

Two important questions are whether and how parents distinguish between schools of different quality and whether they are aware of teacher absence. In-depth interviews with parents in 1997 indicated that they distinguish between schools based on perceptions of teacher absence, teacher effort, and the cleanliness and orderliness of schools (Sathar et al. 2000). ${ }^{7}$ In 1997, while 60 percent of mothers preferred private schools over single-sex government schools for both boys and girls, by 2004 mothers' expressed preference for private schools rose to 74 percent for boys and 70 percent for girls. In 2004, 70 percent of mothers who prefer private schools do so because they believe teachers are better trained and disciplined. In previous work based on the 1997 survey, the share of teachers residing in the village was one of the strongest positive correlates of girls' enrollment in government schools, also suggesting that families respond to a reliable supply of local teachers because they view this as a critical indicator of school quality and accessibility (Lloyd, Mete, and Sathar 2005).

The validity of the notion that parents prefer single-sex schools for their children has been called into question (Andrabi, Das, and Khwaja 2006b). In the 1997 survey, about 85 percent of both mothers and fathers preferred such schools for both boys and girls over coed schools. Most mothers prefer that boys and girls be taught by a teacher of the same sex (80 percent), while fathers are more relaxed about this preference for boys ( 68 percent) than for girls (85 percent). These attitudes changed little over time. Parents' preferences reflect a conflict between a desire to shield children from social interactions involving individuals of the opposite sex and a desire for high-quality schools. Private schools provide better quality but are typically coeducational; and, in our sample, 30 percent of private school teachers are male. 
Private schools tend to hire local women as teachers, to some extent owing to cultural preferences but mainly because they can pay them lower wages than men. In our sample about 70 percent of private school teachers live in the same village as the school. In contrast, 40 percent of teachers in both government boys' and girls' schools are from the same village as the school. After controlling for observed characteristics, in the private sector locally hired teachers earn 23 percent less than non-local ones, and women earn 33 percent less than men (Andrabi, Das, and Khwaja 2006b). In the government sector, the wage differences by teacher residence and gender are considerably smaller. Rural communities have on average only one or two women per village qualified ${ }^{8}$ to become a teacher (World Bank 2005a). Private schools are thus much more likely to be established in villages with government girls' middle and high schools that train low-cost teachers in a context where graduates have few others options (Andrabi, Das, and Khwaja 2006a). Teachers in private schools may be less likely to shirk their daily duties because they live in the same community as the families of students. In Punjab and NWFP, between 80 and 85 percent of schools are owned by an individual (Andrabi, Das, and Khwaja 2002), and having the school proprietor on the premises or nearby may also improve teacher effort and timeliness.

In all countries where teacher absence has been studied, absence levels among men are often higher than or the same as those observed among women. For example, the difference in absence between men and women primary school teachers in India and Bangladesh is 5.3 and 0 percentage points (Chaudhury et al. 2004; Kremer et al. 2005). In Pakistan women are more likely to be absent than men by about 18 percentage points (World Bank 2002b). ${ }^{9}$ Although the higher costs to families of sending young girls rather than boys to school owing to security and safety issues have been noted, less attention has been given to the implications of non-local residence for teacher absence in this context.

\section{DATA}

The data we use were collected in 12 villages purposively selected from six districts (three in Punjab and three in NWFP) to maximize variation in school conditions across communities. In the first round, all currently married women aged 20-45 from a sample of randomly selected households $(\mathrm{N}=649)$ were interviewed between December 1997 and May 1998. In the second round, conducted six years later, the same households were followed up along with those that split off from the original households $(\mathrm{N}=666)$. About 13 percent of households visited in 1997 were lost to follow up in 2004.

Of central interest for our analysis of teachers is the school data collected in both survey rounds. All primary schools attended by at least two children of the women interviewed in the sample were visited: 50 schools were visited in 1997, 104 in 2004. In both surveys three schools were locked or refused participation when visited. The doubling in the number of schools visited was due to the increase in the number of private schools and to the greater mobility of local children who were attending schools outside their community. ${ }^{10}$ The data on schools were collected with the assistance of teachers present during the visit. Because school visits were not announced in advance, we assume that the 
day of the visit was a typical school day. The presence of the teacher was verified through direct observation. ${ }^{11}$ We lack information on whether teachers who were present were in fact engaged in teaching-related activity.

Other information collected about the schools in both surveys included the number of grades taught, details about physical facilities, and the number of students enrolled and present by grade and sex. Out of 1,018 teacher observations in the data, 1,001 contain information on absence from the school. In the analysis, we exclude teachers at schools with low enrollments (e.g., government coed schools or private single-sex schools) because they do not contain enough observations to sustain an analysis by school type. These exclusions leave us with a final sample size of 861 teachers. ${ }^{12}$ Appendix Table A shows sample sizes for the teachers available in each survey round according to school type.

The data on teachers and schools were linked with data on key village characteristics (e.g., type of roads, average proportion of women who are literate) for the villages in the sample. Because of budgetary constraints, the survey did not include village information for schools located outside of these sample villages. The linking of school and teacher information to village-level information is less straightforward in those cases where the school is outside the primary sampling unit (PSU) that contains surveyed families that sent children to the school. However, schools that are located outside the PSU may be located close enough to allow us to ascribe to them the characteristics of the sample village. For our analytic sample of teachers, 7 of 46 schools (in 1997) and 32 of 89 schools (in 2004) were located outside the sample village that sent at least two children to the school. We examined the sensitivity of the estimated effects of village-level characteristics to alternate ways of ascribing village data to the schools located outside the sample PSU. ${ }^{13} \mathrm{We}$ found that the coefficient estimates for the importance of the average level of literacy among women in the village were fairly robust to these sample definitions, hence we retain this item in the regressions for teacher absence shown below.

\section{RESULTS}

Table 1 shows the percentage of teachers who are absent from the school for both time periods. As the bottom portion of the table shows, in 1997 about 35 and 22 percent of teachers in government girls' schools and boys' schools were absent. In 2004, absence rates among teachers in government girls' schools (18 percent) were about half the level in 1997, but remained higher than those in government boys' schools (10 percent). Levels of teacher absence in government schools were higher in Punjab than in NWFP in 1997 (32 vs. 18 percent), and declines were observed in both regions (14 and 9 percent absent in 2004). In the two surveys, absence in government girls' schools is about 1.6 to 1.7 times higher than in government boys' schools. Absence levels in private schools are much lower than in government schools in both time periods ( 4 and 6 percent) and do not differ markedly by province in either survey.

Table 2 shows the percentage of teachers absent according to various teacher and school characteristics for government and private schools separately. Living in the same village as the school or in an adjoining village (rather than a neighboring town) is related to 
a 9 and 11 percentage point lower absence level in government and private schools respectively. The differences in absence levels by whether the teacher has a primary school teaching certificate, has at least 5 years of experience, teaches multiple grades, and whether there is a Parent Teacher Association (PTA) ${ }^{14}$ are either small or not statistically important. The availability of electricity in the school is related to substantially lower absence levels. Teachers in government schools with drinking water are significantly less likely to be absent compared to those in a school without this amenity. Teacher absence is about 4 percentage points lower in government schools with a toilet, and the difference is not significant. These findings show that characteristics of teachers such as having a teaching certificate (which is common only in government schools) or having a college education have no important bivariate association with absence. The amenities in schools (with toilets being the main exception) and the distance teachers must travel from their home to the school are more important.

In Table 3, we show OLS estimates for absence among teachers in government schools only. All variables in the model interact with school type (i.e., with being a teacher in a government girls' school), and the main effects refer to teachers in boys' schools. To keep our results consistent with other studies of provider absence (e.g., Chaudhury et al. 2006; Kremer et al. 2005), we multiply the dependent variable $(1=$ absent, $0=$ present $)$ by 100 so that estimates can be interpreted as the percentage change in absence for a unit change in the independent variables.

Few factors show important correlations with absence among male teachers in government boys' schools. One exception is the pupil to teacher ratio, where a standard deviation rise in the ratio is related to a 4.5 percentage point lower absence rate. PTAs have been advocated as a key way to increase community oversight of schools and monitoring of teachers (World Bank 2002b). The proportion of teachers working in schools with PTAs rose substantially, from 55 percent to 97 percent, between the two surveys. The presence of a PTA is associated with a 7 to 8 percentage point lower absence level.

Proximity to the school is related to lower absence among women teachers. Teachers who live in the same village as the school or in an adjoining village are 18-19 percentage points less likely to be absent. ${ }^{15}$ Note that the unadjusted gender gap in absence levels is 5 percentage points for local teachers (not significant) compared to 17 percentage points for non-local teachers $(\mathrm{p}<.05)$. The negative association between absence and living closer to school among women teaching in girls' schools does not change considerably with inclusion of school-level dummies, suggesting that the association is not attributable to factors related to the location of schools in areas that contain more local teachers or to some other omitted characteristic of schools. ${ }^{16}$

Among girls' schools, the condition of school infrastructure is associated with lower absence: a one-point increase on the school amenities index is related to an 8 percentage point lower absence rate (in a model with district dummies). ${ }^{17}$ Other factors, such as the pupil to teacher ratio and the number of teachers in the school, are positively associated with absence. It is possible that teachers in larger schools may find it easier not to come to school on a given day if other teachers will take over their classes. The positive association may also be due to unobserved and omitted variables, such as a district-level mechanism 
that favors assigning more teachers to schools perceived to have absence problems. The fact that the association with the number of teachers declines with addition of district fixed effects suggests that this latter mechanism may be relevant.

In girls' schools, PTAs have a stronger association with teacher absence than in government boys' schools, although the sign is positive. The presence of a school PTA is related to higher teacher absence on the order of 16 percentage points $(t=1.8$ in a model with control for district). The proportion of teachers in a school with a PTA rose from 77 to 89 percent between the two surveys in government girls' schools. Within girls' schools, the correlation between having a PTA and the literacy levels of women in the sample villages is about .55 (.40 among boys' schools). ${ }^{18}$ One interpretation of the association between PTAs and teacher absence is that parental demand for better schooling and for reduced teacher absence (for example, as reflected in higher average community literacy) encourages the formation of PTAs.

Teachers who are responsible for teaching multiple grades are less likely to be absent by 25 percentage points. A similar result was found in Peru (Rogers et al. 2004). It is difficult to interpret this correlation. It may indicate that better or more responsible teachers are assigned more grades to teach or that teachers who are responsible for multiple grades are less likely to avoid coming to school. About one third of teachers in government schools are responsible for more than one grade, with little change between the two surveys.

Table 4 shows the estimated associations for teachers in private schools. Since the results above suggest that factors such as daily teacher travel time to the school are likely to have different relationships with absence depending on whether teachers are male or female, we allow all right-hand variables to interact with sex of the teacher, and the main effects are for men.

Among male teachers in private schools, years of experience are negatively related to being absent, and the association takes a parabolic shape. As shown by the interactions with teacher's sex, years of experience among female teachers has an inverted U shaped relationship with absence. Years of experience remains an important factor for teacher absence for men and women after including school-level dummies. These findings are interesting in that these more experienced teachers may be former employees of government schools. Perhaps these teachers were dismissed from their jobs since a highly paid government teacher presumably has no incentive to go to a private school, where they would earn substantially less than their previous salary.

Women teachers who live closer to school are more likely to be present, and this association is much larger than for men. Among women, living near the school is related to a 17 percentage point lower absence level, while for men residential proximity to the school results in a 6.7 percentage point lower absence level (in a model with district fixed effects), although for either sex this association is not statistically significant. Once school dummies are included, the association becomes much stronger for women (32 percentage points lower, $\mathrm{t}=2.2$ ), which likely indicates that schools tend to form in or near villages with unobserved characteristics that are related to teacher availability (e.g., the presence of government middle and high schools for girls). All of these findings confirm the potential 
disadvantage in the form of higher teacher absence at those private schools that rely on nonlocal teachers.

\section{Implications of TeACHER AbSEnCE For SCHOOLING ACCESS}

We estimate how teacher absence may affect student access to schooling by calculating the percentage of pupils who do not have a teacher available on the day of the visit to each school. We link enrollment data to the teacher by the grade that he or she is responsible for teaching. We focus on the numbers of students who are officially enrolled rather than those who are reported as being present on the day of our visit. Because teacher absence may negatively affect students' attendance at school, focusing on present students may underestimate the extent to which teacher absence affects students' learning. The correlation between the absence rate of teachers and the percentage of students present per grade is about -.28 in 1997 and -.20 in 2004. Measurement error is likely to be a problem in these enrollment data, and we assume that it is of equal extent across all school types and will not affect the relative comparisons across schools. If a class is taught by more than one teacher, we assume that the effect of each teacher's absence is proportionate to the share of teachers that the absent teacher represents for each grade. For example, if a grade is taught by two teachers and one is absent, we assume that students lose half of their teaching time rather than all of the time for that day. This assumption is unlikely to substantially affect the estimates shown below since a very small number of primary grades are taught by more than one teacher. We cannot distinguish whether, for example, the teacher was gone for the entire day or part of the day, or whether other teachers in the school substituted for the absent teacher.

The first and third columns of Table 5 indicate the total numbers of students enrolled by school type and sex in 1997 and 2004. ${ }^{19}$ The number of students enrolled in private schools quadrupled between the two surveys. The share of 5-9-year-olds enrolled in private schools rose from about 20 percent to 40 percent (Sathar et al. 2000). Much of this increase is due to the establishment of new private schools in the period between the two surveys (see endnote 10). In 1997, nearly 25 percent of girls enrolled in government girls' schools did not have a teacher present at the time of the school visit. In boys' schools, about 17 percent of enrolled pupils did not have a teacher present. By the second survey, these percentages declined to 15 percent of girls and 10 percent of boys owing to a drop in teacher absence. Girls enrolled in boys' schools or private schools are less likely to incur a loss of learning time than their counterparts in government girls' schools.

In Table 6 we examine the ratio of the number of teachers officially assigned to each class to the total number of classes taught in each school (for grades 1 to 5). We calculate the same ratio using the number of teachers who came to school on the day of the visit. $^{20}$ In 1997, most schools offered five primary school classes, thus the mean number of classes is 4.9 with a small standard deviation. There are between 4.4 and 4.7 teachers per school. In 2004, government boys' schools and private schools offer about one more class per school and contain nearly two more teachers per school. Girls' schools continue to offer five classes and show less expansion in the number of available teachers. 
In 1997, the ratio of teachers per class was between 0.8 for government schools and nearly 0.9 for private schools. If we take into account teacher absence, the ratio in government girls' schools is about 0.5 . In other words, only one teacher is present, on average, for every two classes. In boys' school, about one teacher is present for every 1.5 classes. By 2004, owing to a decline in absence rates, girls' schools have about one present teacher for every 1.5 classes, the same level as in boys' schools in 1997. In boys' schools in 2004 , the ratio of present teachers to classes is higher at .74. In private schools, there is about one teacher per class.

Because class sizes can vary within a school, we also examine the ratio of enrolled students per teacher. In 1997, there were 27-28 students per teacher in government schools. If we account for teacher absence, for each available teacher there are 35 students in government boys' schools and 42 students in government girls' schools. This represents an increase of one third and one half in the number of students per teacher in boys' and girls' schools. In the 2004 survey, the average number of students per present teacher is similar to the average number of students per teacher in government boys' schools and private schools. However, in government girls' schools, there are about 9 more pupils per present teacher compared to pupils per teacher, representing about a 33 percent increase. Teacher absence thus takes a larger toll on teacher availability per class and per student in government girls' schools than in government boys' schools or private schools. The decline in teacher absence over time has reduced the percentage of students who lack a teacher in government schools, although the average gender gap of 7 percentage points in 1997 largely remains in 2004 .

Educators and policymakers place increasing emphasis on designing education goals and policies that focus not on universal enrollment and school completion but on ensuring that children achieve minimal competencies and skills needed to be productive adults (e.g., Filmer, Hasan, and Pritchett 2006). We are not able to examine the association of teacher absence with student learning because we do not have the requisite data on student achievement. It is reasonable to believe that higher teacher absence in government schools will compromise student learning because it results in less teaching time and more multi-grade teaching in a context where teachers are unlikely to receive the training required to teach multiple classes. Higher student/ teacher ratios are associated with lower student learning in several countries (see National Research Council and Institute of Medicine 2005, pp. 135-137). In India, a carefully executed experimental program that reduced teacher absence by one half led to a 30 percent increase in teaching time and a .17 standard deviation rise in achievement test scores (Duflo and Hanna 2005). A recent assessment in Pakistan indicates that government schools lag far behind private schools in student test scores in Urdu, mathematics, and particularly English (Das, Pandey, and Zajonc 2006). The nature and extent of achievement gaps within the government sector are not known, although our findings warrant investigating whether girls fare as well as boys in government schools. 


\section{CONCLUSION}

Pakistan has become a focus of international political interest in recent years. Much progress remains to be made in ensuring that children, particularly in rural areas of Pakistan, are going to school and learning while in school. There are reasons for optimism. In 1997, teacher absence in government schools was commonplace; seven years later it appears to have declined in both NWFP and Punjab. Among the factors strongly associated with lower female teacher absence in government schools in Pakistan is better school infrastructure, suggesting that recent investments in education may have paid off by reducing absences. Women teachers in both government and private schools are more likely to be absent than male teachers when they reside farther from the schools in which they teach.

The gender differences in absence rates among teachers in government schools may have implications for the feasibility of girls' access to education in the context of sex segregation within government primary schools. In 2004, 10 percent of boys enrolled in government boys' schools had an absent teacher on a given school day, compared with 15 percent of girls enrolled in government girls' schools. By contrast, there was essentially no gender gap in the percent of students experiencing teacher absence in private schools. The preference for single-sex schools and same-sex teachers for children, especially girls, may wane in the face of increasing availability of coeducational private schools of better quality. The market may also adapt through formation of single-sex private schools in some communities. As an example, Iran has addressed the shortage of women teachers by allowing coeducational classrooms and male teachers in rural areas and by permitting men to teach math and science to girls (Mehran 2003).

Whether through the formation of new private or government schools, coed classrooms, cash incentives to families to send girls to school, or hiring more teachers per school, solutions to expand schooling access for girls in Pakistan will encounter the constraint that there are not enough women teachers. While the construction of girls' middle and high schools to educate women to become teachers will ease some of the supply constraints, progress will be gradual. It will be useful to design and test creative solutions that can be tailored to local conditions and rigorously evaluated in terms of their impact on teacher attendance, student attendance, and learning. In India, student achievement was increased substantially by placing additional teachers from the community in schools (Banerjee et al. 2006), and this approach may be worth trying in Pakistan. Private schools' operating costs will increase as hiring of male teachers and non-local teachers becomes increasingly necessary. Non-local teachers may need to be provided with transportation or other monetary incentives to secure regular attendance. In our sample, the proportion of male private schools teachers rose from 15 to 30 percent and the share of non-local teachers rose from 25 to 44 percent between the two surveys, suggesting that these shifts may already have started. 


\section{NoTES}

1 See, for example: Alcazar et al. 2006; Banerjee, Deaton, and Duflo 2004; Banerjee and Duflo 2006; Chaudhury et al. 2004, 2006; Duflo and Hanna 2005; Glewwe, Ilias, and Kremer 2003; Kremer et al. 2004; PROBE Team 1999; Rogers et al. 2004.

2 The six countries (percent of teachers absent) are: Bangladesh (16), Ecuador (14), India (25), Indonesia (19), Peru (11), and Uganda (27).

3 The majority of private schools use English-language instructional materials compared to none of the government schools in our sample. Less than 1 percent of enrolled children aged 5-15 in Pakistan attend religious schools, or madrassas (Andrabi et al. 2006).

4 These figures likely underestimate the lack of access to a school because they are measured at the level of a primary sampling unit (PSU) and the schools may be at a substantial distance from some households (World Bank 2005a, note 96). In earlier years, the government followed a rough rule of thumb, building one girls' primary school for every two boys' schools (Warwick and Reimers 1995).

5 The teachers have a primary teaching certificate, a teaching certificate, or both (82 percent); a bachelor's degree in education (12 percent); or other training (6 percent). In private schools, about 28 percent have a primary teaching certificate, a teaching certificate, or both; and 4 percent have a bachelor's degree in education. These findings are broadly consistent with results from a national census of private schools reported by Andrabi, Das, and Khwaja 2006b.

6 Another reason for higher absence may be relatively generous leave policies. Head teachers in government schools were entitled to about 13 leave days in the past year compared to 6 days in private schools (Andrabi, Das, and Khwaja 2002, Table 4).

7 Within the six districts in our study, interviews were conducted with 22 mothers and 23 fathers who had children of primary school age.

8 In this case defined as having at least 8 grades of schooling (or middle school completion) (World Bank 2005a). In the government sector virtually all teachers have completed at least 10 grades of schooling (at least secondary).

9 Teachers in the government sector are substantially more likely to be married and on average are about 13 years older than private school teachers (Andrabi, Das, and Khwaja 2006b). This suggests that childcare or domestic responsibilities are also a factor in higher absence of government (girls') school teachers.

10 There were 36 government schools in the sample in 1997 and 50 in 2004; only 2 were established after 1997. There were 12 private for-profit schools in 1997 and 47 
in 2004, of which 26 were established after 1997, particularly from 2001 to 2003 (Sathar et al. 2006).

11 We were unable to account for absences due to being on leave for official schoolrelated duties, or to sickness and personal emergencies. Estimates from Ecuador and Peru suggest that one third to nearly half of absent teachers were on leave for official or personal reasons (Alcazar et al. 2006; Rogers et al. 2004). If we assume these estimates are valid and apply to Pakistan, this leaves substantial proportions of teachers absent for other reasons. From the perspective of the enrolled student, teacher absence means a loss of exposure to learning irrespective of the reason for absence.

12 In the analysis we combined 53 teachers in six NGO schools in 2004 with those in private for-profit schools because, on average, they are very similar with respect to individual characteristics, the school environment, and teacher absence.

13 Specifically, we examined whether the estimates differ when we linked village-level data to schools located within 1 kilometer of the sample block or to schools located within $2 \mathrm{~km}$ of the sample block, or when we linked the school information to village information based on whether the village sent at least 2 children to the particular school irrespective of the distance between the school and the sample block.

14 Since information on whether the PTA is active was collected in 2004 only, for 1997 this variable refers to the existence of a PTA irrespective of whether it was active. In 2004, about 80 percent of PTAs were reported as active. The associations between teacher absence and a PTA in Table 3 (negative for boys' schools and positive for girls' schools) are similar in sign but smaller in magnitude if PTAs are considered regardless of whether they are active.

15 In the regressions, although the negative relationship between teacher absence and living near a school is generally larger among teachers who live in the same village compared to those who live in the adjoining village (where the reference group is those who live in a town nearby), the differences between these two categories were not statistically significant so we combine them into a single category.

16 This finding is consistent with results from other countries (e.g., Chaudhury et al. 2006).

17 The index contains five items: school has electricity, intact boundary wall, toilet, drinking water, and is fully furnished.

18 Although the correlation is also positive for schools outside the sample villages, it is computed for schools inside the sample villages, where it is more meaningful. 
19 Children of the opposite sex are occasionally allowed to attend a single-sex school.

20 More than one class may be taught per grade. We exclude three government boys' school that had unusually large numbers of classes taught and teachers present and thus influenced the averages disproportionately.

\section{REFERENCES}

Alcazar, Lorena, F. Halsey Rogers, Nazmul Chaudhury, Jeffrey Hammer, Michael Kremer, and Karthik Muralidharan. 2006. "Why are teachers absent? Probing service delivery in Peruvian primary schools." Group for the Analysis of Development, Harvard University and World Bank.

Al-Nayadi, M.A. 1994. "United Arab Emirates.” Pp. 6511-6515 in Torsten Husen and T. Neville Postlethwaite (eds.), International Encyclopedia of Education, $2^{\text {nd }}$ edition, 12 vols. New York: Pergamon; Elsevier Science.

Andrabi, Tahir, Jishnu Das, and Asim Ijaz Khwaja. 2002. "The rise of private schooling in Pakistan: Catering to the urban elite or educating the rural poor?" Harvard University, Pomona College, and World Bank.

-2006a. "Students today, teachers tomorrow? The rise of affordable private schools [in Pakistan]." Harvard University, Pomona College, and World Bank.

- 2006b. "A dime a day: The possibilities and limits of private schooling in Pakistan," Policy Research Working Paper 4066, November, Washington, DC: World Bank.

Andrabi, Tahir, Jishnu Das, Asim Ijaz Khwaja, and Tristan Zajonc. 2006. "Religious school enrollment in Pakistan," Comparative Education Review 50(3): 548-549.

Banerjee, Abhijit and Esther Duflo. 2006. "Addressing absence," Journal of Economic Perspectives 20(1): 117-132.

Banerjee, Abhijit, Angus Deaton, and Esther Duflo. 2004. "Wealth, health, and health services in rural Rajasthan," American Economic Review 94(2): 326-330.

Banerjee, Abhijit, Shawn Cole, Esther Dulfo, and Leigh Linden. 2006. "Remedying education: Evidence from two randomized experiments in India," Poverty Action Lab Working Paper.

Battle-Walters, Kimberly A. 2002. “Oman.” Pp. 1007-1010 in Rebecca Marlow-Ferguson (ed.), World Education Encyclopedia: A Survey of Educational Systems Worldwide, 3 vols. Detroit: Gale Group/Thomson Learning. 
Brewer, Dominic J., Charles A. Goldman, Catherine H. Augustine, Gail L. Zellman, Gery Ryan, Cathleen Stasz, and Louay Constant. 2006. "An introduction to Qatar's primary and secondary education reform." RAND Education Working Paper WR399-SEC. Santa Monica: RAND Corporation.

Browne, Dallas L. 2002. "Libya." Pp. 808-816 in Rebecca Marlow-Ferguson (ed.), World Education Encyclopedia: A Survey of Educational Systems Worldwide, 3 vols. Detroit: Gale Group/Thomson Learning.

Chaudhury, Nazmul, Jeffrey Hammer, Michael Kremer, Karthik Muralidharan, and F. Halsey Rogers. 2004. "Roll call: Teacher absence in Bangladesh." Harvard University and World Bank.

- 2006. "Missing in action: Teacher and health worker absence in developing countries," Journal of Economic Perspectives 20(1): 91-116.

Das, Jishnu, Priyanka Pandey, and Tristan Zajonc. 2006. "Learning levels and gaps in Pakistan," Policy Research Working Paper 4067, November. Washington, DC: World Bank.

Duflo, Esther and Rema Hanna. 2005. "Monitoring works: Getting teachers to come to school," Working Paper No. 103. Bureau for Research in Economic Analysis of Development (BREAD).

Easterly, William. 2003. The political economy of growth without development," in Dani Rodrik (ed.), In Search of Prosperity: Analytic Narratives on Economic Growth. Princeton, NJ: Princeton University Press.

Filmer, Deon, Amer Hasan, and Lant Pritchett. 2006. "A millennium learning goal: Measuring real progress in education.” Working Paper 97, August. Washington, DC: Center for Global Development

Glewwe, Paul, Nauman Ilias, and Michael Kremer. 2003. "Teacher incentives," Working Paper 9672. Cambridge, MA: National Bureau of Economic Research.

Hamdan, Amani. 2005. "Women and education in Saudi Arabia: Challenges and achievements." International Education Journal 6(1): 42-64.

Hasnain, Zahid. 2005. "The politics of service delivery in Pakistan: Political parties and the incentives for patronage 1988-1999," South Asia Region, Poverty Reduction and Economic Management Sector Unit, Working Paper Series, Report No SASPR-6. Washington, DC: World Bank. 
Kremer, Michael, Karthik Muralidharan, Nazmul Chaudhury, Jeffrey Hammer, and F. Halsey Rogers. 2005. "Teacher absence in India: A snapshot," Journal of the European Economic Association 3(2-3): 658-667.

Lesko, John P. 2002a. "Bahrain." Pp. 92-98 in Rebecca Marlow-Ferguson (ed.), World Education Encyclopedia: A Survey of Educational Systems Worldwide, 3 vols. Detroit: Gale Group/Thomson Learning.

—. 2002b. "Kuwait." Pp. 747-757 in Rebecca Marlow-Ferguson (ed.), World Education Encyclopedia: A Survey of Educational Systems Worldwide, 3 vols. Detroit: Gale Group/Thomson Learning.

Lloyd, Cynthia B. 2004. 'The changing transitions to adulthood in a comparative perspective: The case of Pakistan," Pakistan Development Review 43(4): 441-467.

Lloyd, Cynthia B., Cem Mete, and Zeba A. Sathar. 2005. "The effect of gender differences in primary school access, type, and quality on the decision to enroll in rural Pakistan," Economic Development and Cultural Change 53(3): 685-710.

Mehran, Golnar. 2003. "The paradox of tradition and modernity in female education in the Islamic Republic of Iran," Comparative Education Review 43(3): 269-286.

National Research Council and Institute of Medicine. 2005. Growing Up Global: The Changing Transitions to Adulthood in Developing Countries. Panel on Transitions to Adulthood in Developing Countries. Cynthia B. Lloyd, ed. Washington, DC: National Academies Press.

Obeidat, Osama M. 2002. “Jordan.” Pp. 706-719 in Rebecca Marlow-Ferguson (ed.), World Education Encyclopedia: A Survey of Educational Systems Worldwide, 3 vols. Detroit: Gale Group/Thomson Learning.

PROBE Team. 1999. Public Report on Basic Education in India (PROBE). Oxford: Oxford University Press.

Rogers, F. Halsey, Jose Lopez-Calix, Nazmul Chaudhury, Jeffrey Hammer, Nancy Cordoba, and Michael Kremer. 2004. Teacher Absence and Incentives in Primary Education: Results from a National Teacher Tracking Survey in Ecuador. $<<$ http://siteresources.worldbank.org/DEC/Resources/37912_Ecuador.Teacher.Abse nce.August13.2004.pdf $>>$

Sathar, Zeba, Cynthia B. Lloyd, and Minhaj ul Haque. 2000. Investments in Children's Education and Family-Building Behavior in Pakistan: Findings from Rural NWFP and Punjab. Islamabad: Population Council. 
Sathar, Zeba, Minhaj ul Haque, Mumraiz Khan, Cynthia Lloyd, and Monica Grant. 2006. Fewer and Better Educated Children: Expanded Choices in Schooling and Fertility in Rural Pakistan. Islamabad and New York: Population Council.

Warwick, Donald P., and Fernando Reimers. 1995. Hope or Despair? Learning in Pakistan's Primary Schools. Westport, CT: Praeger.

World Bank. 2002a. "Improving human development outcomes in Pakistan." Background Note Prepared for the Pakistan Human Development Forum, Islamabad, 24-26 January.

- 2002b. Poverty in Pakistan: Vulnerabilities, Social Gaps, and Rural Dynamics. Poverty Reduction and Economic Management Sector Unit, South Asia Region, Report No. 24296-PAK. Washington, DC: World Bank.

- 2005a. Country Gender Assessment. Bridging the Gender Gap: Opportunities and Challenges. Environment and Social Development Sector Unit, South Asia Region, Report No. 32444-PAK.

- 2005b. Implementation Completion Report No. 32493 (TF-50893 IDA-39320) On a Credit in the Amount of SDR 62.1 Million to the Islamic Republic of Pakistan for a Second Structural Adjustment Credit for the Government of North West Frontier Province. 22 June 2005. Poverty Reduction and Economic Management Unit, South Asia Region.

- 2005c. Afghanistan: National Reconstruction and Poverty Reduction-the Role of Women in Afghanistan's Future. Environment and Social Unit (SASES), South Asia Region.

- n.d. EdStats—World Bank Database of Education Statistics. Accessed 10 August 2006: <http://devdata.worldbank.org/edstats/>> 
Table 1 Percentage of teachers absent by school type and survey round

$1997 \quad 2004 \quad$ Total

School type

Government

Private

NGO

Total

De jure status

Girls'

Boys'

Mixed

Total

n.a. = not applicable.
$26.2 \quad 12.7 \quad 18.6$

$\begin{array}{lll}4.4 & 6.3 & 5.8\end{array}$

n.a. $\quad 5.7 \quad 5.7$

$19.0 \quad 8.9 \quad 12.2$

$\begin{array}{lll}34.9 & 17.7 & 25.2\end{array}$

$21.5 \quad 10.1 \quad 15.0$

$\begin{array}{lll}4.4 & 6.2 & 5.8\end{array}$

$\begin{array}{lll}19.0 & 8.9 & 12.2\end{array}$ 
Table 2 Percentage of teachers absent by teacher and school variables

\begin{tabular}{|c|c|c|c|c|}
\hline \multirow[b]{2}{*}{ Variable } & \multicolumn{2}{|c|}{ Government } & \multicolumn{2}{|c|}{ Private } \\
\hline & No & Yes & No & Yes \\
\hline Has a teaching certificate & 20.0 & 18.7 & 6.6 & 2.2 \\
\hline Teacher is male & 25.0 & $15.1 \dagger$ & 5.3 & 7.2 \\
\hline Lives in same/adjoining village as school & 24.2 & $15.9 \dagger$ & 15.0 & $3.7^{*}$ \\
\hline Teaches multiple grades & 18.6 & 19.0 & 3.7 & $8.1 \sim$ \\
\hline Has college education & 18.2 & 18.8 & 6.7 & 4.6 \\
\hline Has at least 5 years experience as teacher & 25.0 & 17.1 & 5.7 & 4.0 \\
\hline Drinking water available & 30.7 & $15.8 *$ & 10.0 & 5.7 \\
\hline Electricity available & 27.2 & $12.9 *$ & 27.2 & $5.3^{*}$ \\
\hline Toilet available & 21.0 & 16.6 & 0 & 6.1 \\
\hline School walls fully enclosed & 19.7 & 18.3 & 20.0 & 5.7 \\
\hline Parent Teacher Association exists & 19.7 & 18.5 & 5.8 & 5.9 \\
\hline
\end{tabular}


Table 3 OLS estimates for teacher absence, government schools

\begin{tabular}{|c|c|c|c|}
\hline Variable & $\begin{array}{c}\text { Without } \\
\text { district or } \\
\text { school } \\
\text { fixed } \\
\text { effects }\end{array}$ & $\begin{array}{l}\text { With district } \\
\text { fixed effects }\end{array}$ & $\begin{array}{l}\text { With school } \\
\text { fixed effects }\end{array}$ \\
\hline \multicolumn{4}{|l|}{ Teacher characteristics } \\
\hline Has a teaching certificate & $\begin{array}{r}-3.12 \\
{[.38]}\end{array}$ & $\begin{array}{l}-4.07 \\
{[.49]}\end{array}$ & $\begin{array}{l}-9.01 \\
{[.94]}\end{array}$ \\
\hline Has 12 years of schooling (matriculation) & $\begin{array}{l}-8.16 \\
{[1.59]}\end{array}$ & $\begin{array}{l}-7.15 \\
{[1.35]}\end{array}$ & $\begin{array}{l}-7.32 \\
{[1.30]}\end{array}$ \\
\hline Has $12+$ years of schooling (B.A. or above) & $\begin{array}{l}1.53 \\
{[.21]}\end{array}$ & $\begin{array}{l}2.34 \\
{[.32]}\end{array}$ & $\begin{array}{r}-1.68 \\
{[.19]}\end{array}$ \\
\hline Years of experience & $\begin{array}{l}.278 \\
{[.37]}\end{array}$ & $\begin{array}{l}.331 \\
{[.38]}\end{array}$ & $\begin{array}{l}-.250 \\
{[.23]}\end{array}$ \\
\hline Years of experience squared & $\begin{array}{l}-.014 \\
{[.67]}\end{array}$ & $\begin{array}{l}-.014 \\
{[.60]}\end{array}$ & $\begin{array}{l}.00006 \\
{[0.00]}\end{array}$ \\
\hline Lives in same/adjoining village as school & $\begin{array}{l}-.478 \\
{[.11]}\end{array}$ & $\begin{array}{l}-.079 \\
{[.02]}\end{array}$ & $\begin{array}{l}1.72 \\
{[.33]}\end{array}$ \\
\hline Teaches multiple grades & $\begin{array}{l}5.26 \\
{[.83]}\end{array}$ & $\begin{array}{l}4.76 \\
{[.72]}\end{array}$ & $\begin{array}{l}8.69 \\
{[.80]}\end{array}$ \\
\hline \multicolumn{4}{|l|}{ School characteristics } \\
\hline Amenities index $(0-5)$ & $\begin{array}{l}1.73 \\
{[.83]}\end{array}$ & $\begin{array}{l}2.11 \\
{[.91]}\end{array}$ & \\
\hline Number of teachers & $\begin{array}{l}-.849 \\
{[1.45]}\end{array}$ & $\begin{array}{l}-.670 \\
{[.89]}\end{array}$ & \\
\hline Pupil to teacher ratio & $\begin{array}{l}-.399 \dagger \\
{[2.15]}\end{array}$ & $\begin{array}{l}-.448 \dagger \\
{[2.04]}\end{array}$ & \\
\hline PTA exists & $\begin{array}{l}-7.60 \\
{[1.21]}\end{array}$ & $\begin{array}{l}-8.46 \\
{[1.25]}\end{array}$ & \\
\hline Government girls' school & $\begin{array}{l}6.34 \\
{[.16]}\end{array}$ & $\begin{array}{l}4.88 \\
{[.11]}\end{array}$ & \\
\hline \multicolumn{4}{|l|}{ Village characteristics } \\
\hline Mean literacy of women in village & $\begin{array}{r}-7.93 \\
{[.51]}\end{array}$ & $\begin{array}{l}-33.4 \\
{[1.18]}\end{array}$ & \\
\hline Survey year $(1=2004)$ & $\begin{array}{c}-10.3 \\
{[1.46]}\end{array}$ & $\begin{array}{l}-9.04 \\
{[1.22]}\end{array}$ & \\
\hline \multicolumn{4}{|c|}{$\begin{array}{l}\text { Interactions with government girls' school of: } \\
\text { Teacher characteristics }\end{array}$} \\
\hline Has a teaching certificate & $\begin{array}{l}-4.05 \\
{[.21]}\end{array}$ & $\begin{array}{l}-2.7 \\
{[.14]}\end{array}$ & $\begin{array}{c}16.2 \\
{[.75]}\end{array}$ \\
\hline Has 12 years of schooling & $\begin{array}{l}6.03 \\
{[.46]}\end{array}$ & $\begin{array}{l}5.43 \\
{[.40]}\end{array}$ & $\begin{array}{l}3.87 \\
{[.27]}\end{array}$ \\
\hline Has $12+$ years of schooling & $\begin{array}{l}-.476 \\
{[.03]}\end{array}$ & $\begin{array}{l}-.757 \\
{[.05]}\end{array}$ & $\begin{array}{l}3.98 \\
{[.27]}\end{array}$ \\
\hline Years of experience & 1.21 & 1.05 & -1.36 \\
\hline
\end{tabular}




\begin{tabular}{|c|c|c|c|}
\hline Variable & $\begin{array}{l}\text { Without } \\
\text { district or } \\
\text { school } \\
\text { fixed } \\
\text { effects }\end{array}$ & $\begin{array}{l}\text { With district } \\
\text { fixed effects }\end{array}$ & $\begin{array}{l}\text { With school } \\
\text { fixed effects }\end{array}$ \\
\hline \multirow{3}{*}{ Years of experience squared } & {$[.38]$} & {$[.32]$} & {$[.39]$} \\
\hline & -.029 & -.028 & .038 \\
\hline & {$[.087]$} & {$[.32]$} & {$[.41]$} \\
\hline \multirow[t]{2}{*}{ Lives in same/adjoining village as school } & $-18.8 \dagger$ & $-18.2 \sim$ & $-22.8 \dagger$ \\
\hline & {$[-2.05]$} & {$[1.86$} & {$[2.12]$} \\
\hline Teaches multiple grades & $\begin{array}{c}-29.1 \sim \\
{[1.86]}\end{array}$ & $\begin{array}{c}-29.5 \sim \\
{[1.74]}\end{array}$ & $\begin{array}{c}-42.8 \sim \\
{[1.99]}\end{array}$ \\
\hline \multicolumn{4}{|l|}{ School characteristics } \\
\hline \multirow{2}{*}{ Amenities index $(0-5)$} & $-9.70 \dagger$ & $-9.87 \dagger$ & \\
\hline & {$[2.04]$} & {$[2.03]$} & \\
\hline \multirow[t]{2}{*}{ Number of teachers } & $4.98 \dagger$ & $4.76 \sim$ & \\
\hline & {$[2.48]$} & {$[1.69]$} & \\
\hline \multirow[t]{2}{*}{ Pupil to teacher ratio } & $.658 \sim$ & $.730 \sim$ & \\
\hline & {$[1.76]$} & {$[1.99]$} & \\
\hline \multirow[t]{2}{*}{ PTA exists } & $28.3 \dagger$ & $24.6 \sim$ & \\
\hline & {$[2.33]$} & {$[1.86]$} & \\
\hline \multicolumn{4}{|l|}{ Village characteristics } \\
\hline \multirow[t]{2}{*}{ Mean literacy of women } & $-54.3 \sim$ & -43.2 & \\
\hline & {$[1.86]$} & {$[1.37]$} & \\
\hline \multirow[t]{2}{*}{ Constant } & $43.6 \dagger$ & 43.7 & -82.6 \\
\hline & {$[2.49]$} & {$[1.85]$} & {$[2.37]$} \\
\hline F test for interactions & 2.47 & 2.26 & 1.73 \\
\hline [p-value] & {$[.009]$} & {$[.018]$} & {$[.117]$} \\
\hline Number of observations & 327 & 327 & 327 \\
\hline R squared & .19 & .19 & .30 \\
\hline
\end{tabular}

Note: Standard errors corrected for clustering at the school level. The binary dependent variable $(1=$ absent, $0=$ present) has been multiplied by 100 so that coefficients represent the percentage change in absence for a unit increase in each variable. Absolute values of $t$ statistics are shown in brackets. Models include controls for day of week of school visit.

$\sim \mathrm{p}<.10+\mathrm{p}<.05 * \mathrm{p}<.01$ 
Table 4 OLS estimates for teacher absence, private schools

\begin{tabular}{|c|c|c|c|}
\hline Variable & $\begin{array}{c}\text { Without } \\
\text { district or } \\
\text { school } \\
\text { fixed } \\
\text { effects }\end{array}$ & $\begin{array}{l}\text { With district } \\
\text { fixed effects }\end{array}$ & $\begin{array}{l}\text { With school } \\
\text { fixed effects }\end{array}$ \\
\hline \multicolumn{4}{|l|}{ Teacher characteristics } \\
\hline \multirow[t]{2}{*}{$\operatorname{Sex}(1=$ female, $0=$ male $)$} & 16.7 & -30.2 & 111.7 \\
\hline & {$[.50]$} & {$[.74]$} & {$[1.22]$} \\
\hline \multirow[t]{2}{*}{ Has teaching certificate } & -2.67 & -1.86 & 2.18 \\
\hline & {$[1.00]$} & {$[.58]$} & {$[.74]$} \\
\hline \multirow[t]{2}{*}{ Has 12 years of schooling (matriculation) } & 2.34 & .989 & 3.23 \\
\hline & {$[.24]$} & {$[.10]$} & {$[.29]$} \\
\hline \multirow[t]{2}{*}{ Has $12+$ years of schooling (B.A. or above) } & -4.23 & -6.4 & -3.33 \\
\hline & {$[.62]$} & {$[.84]$} & {$[.39]$} \\
\hline \multirow[t]{2}{*}{ Years of experience } & $-3.83 \dagger$ & $-3.90 \dagger$ & $-4.11 *$ \\
\hline & {$[2.59]$} & {$[2.58]$} & {$[2.71]$} \\
\hline \multirow[t]{2}{*}{ Yrs of experience squared } & $.109 \dagger$ & $.112 \dagger$ & $.114 \dagger$ \\
\hline & [2.61] & {$[2.60]$} & [2.61] \\
\hline \multirow[t]{2}{*}{ Lives in same/adjoining village as school } & -7.18 & -6.67 & -5.27 \\
\hline & {$[.83]$} & {$[.77]$} & {$[.29]$} \\
\hline \multirow[t]{2}{*}{ Teaches multiple grades } & 2.02 & 2.06 & 5.35 \\
\hline & {$[.48]$} & {$[.51]$} & {$[1.23]$} \\
\hline \multicolumn{4}{|l|}{ School characteristics } \\
\hline \multirow[t]{2}{*}{ Amenities index $(0-5)$} & 3.03 & 4.46 & \\
\hline & {$[.52]$} & {$[.48]$} & \\
\hline \multirow[t]{2}{*}{ Number of teachers } & -.494 & -.475 & \\
\hline & {$[1.58]$} & [1.21] & \\
\hline \multirow[t]{2}{*}{ Pupil to teacher ratio } & -.456 & -.505 & \\
\hline & {$[.58]$} & {$[.48]$} & \\
\hline \multirow[t]{2}{*}{ PTA exists } & .235 & -.351 & \\
\hline & {$[.05]$} & {$[.09]$} & \\
\hline \multicolumn{4}{|l|}{ Village characteristics } \\
\hline \multirow[t]{2}{*}{ Mean literacy of women } & 18.1 & 40.3 & \\
\hline & {$[.96]$} & [1.65] & \\
\hline \multirow[t]{2}{*}{ Survey year $(1=2004)$} & -2.53 & -3.42 & \\
\hline & {$[.63]$} & {$[.86]$} & \\
\hline \multirow{2}{*}{\multicolumn{4}{|c|}{$\begin{array}{l}\text { Interactions with teacher sex: } \\
\text { Teacher characteristics }\end{array}$}} \\
\hline & & & \\
\hline \multirow[t]{2}{*}{ Has teaching certificate } & -3.17 & -3.11 & -6.42 \\
\hline & {$[.86]$} & {$[.81]$} & [1.59] \\
\hline \multirow[t]{2}{*}{ Has 12 years of schooling } & 1.88 & 3.72 & 3.85 \\
\hline & {$[.18]$} & {$[.33]$} & {$[.32]$} \\
\hline \multirow[t]{2}{*}{ Has $12+$ years of schooling } & 11.2 & 13.8 & 11.4 \\
\hline & {$[1.41]$} & {$[1.61]$} & [1.19] \\
\hline Years of experience & $5.93 *$ & $5.64 *$ & $5.41 *$ \\
\hline
\end{tabular}




\begin{tabular}{|c|c|c|c|}
\hline Variable & $\begin{array}{c}\text { Without } \\
\text { district or } \\
\text { school } \\
\text { fixed } \\
\text { effects }\end{array}$ & $\begin{array}{l}\text { With district } \\
\text { fixed effects }\end{array}$ & $\begin{array}{l}\text { With school } \\
\text { fixed effects }\end{array}$ \\
\hline \multirow{3}{*}{ Years of experience squared } & {$[3.56]$} & {$[3.20]$} & {$[3.30]$} \\
\hline & $-.238^{*}$ & $-.209 \dagger$ & $-.166^{*}$ \\
\hline & {$[3.22]$} & {$[2.63]$} & {$[3.08]$} \\
\hline \multirow[t]{2}{*}{ Lives in same/adjoining village as school } & -9.26 & -10.8 & $-26.7 \dagger$ \\
\hline & {$[.84]$} & {$[.97]$} & {$[2.24]$} \\
\hline \multirow[t]{2}{*}{ Teaches multiple grades } & -1.76 & -1.31 & -6.58 \\
\hline & {$[.29]$} & {$[.21]$} & [1.14] \\
\hline \multicolumn{4}{|l|}{ School characteristics } \\
\hline \multirow{2}{*}{ Amenities index $(0-5)$} & -8.05 & -9.16 & \\
\hline & {$[1.08]$} & {$[.86]$} & \\
\hline \multirow[t]{2}{*}{ Number of teachers } & -.027 & -.375 & \\
\hline & {$[.05]$} & {$[.58]$} & \\
\hline \multirow[t]{2}{*}{ Pupil to teacher ratio } & .566 & .619 & \\
\hline & {$[.69]$} & {$[.58]$} & \\
\hline \multirow[t]{2}{*}{ PTA exists } & -2.47 & -3.17 & \\
\hline & {$[.30]$} & {$[.42]$} & \\
\hline \multicolumn{4}{|l|}{ Village characteristics } \\
\hline \multirow[t]{2}{*}{ Mean literacy of women } & -24.8 & -38.9 & \\
\hline & [1.34] & {$[1.54]$} & \\
\hline \multirow[t]{2}{*}{ Constant } & 27.5 & 24.8 & \\
\hline & {$[1.01]$} & {$[.82]$} & \\
\hline F test for interactions & 1.57 & 1.79 & 3.25 \\
\hline [p-value] & {$[.128]$} & {$[.073]$} & {$[.001]$} \\
\hline Number of observations & 403 & 403 & 403 \\
\hline $\mathrm{R}$ squared & .17 & .18 & .37 \\
\hline
\end{tabular}

Note: Standard errors corrected for clustering at the school level. The binary dependent variable $(1=$ absent, $0=$ present) has been multiplied by 100 so that coefficients represent the percentage change in absence for a unit increase in each variable. Absolute values of $t$ statistics are shown in brackets. Models include controls for day of week of school visit.

$\sim \mathrm{p}<.10+\mathrm{p}<.05 * \mathrm{p}<.01$ 
Table 5 Numbers and percentages of enrolled students with an absent teacher

\begin{tabular}{|c|c|c|c|c|}
\hline \multirow[b]{2}{*}{ Student/school type } & \multicolumn{2}{|c|}{$\begin{array}{c}\text { Survey Year } \\
1997 \\
\end{array}$} & \multicolumn{2}{|c|}{$\begin{array}{c}\text { Survey Year } \\
2004 \\
\end{array}$} \\
\hline & $\begin{array}{c}\text { Enrolled } \\
\text { students } \\
\text { (grades 1-5) }\end{array}$ & $\begin{array}{c}\text { Percent of } \\
\text { enrolled } \\
\text { students with } \\
\text { teacher } \\
\text { absent } \\
\end{array}$ & $\begin{array}{c}\text { Enrolled } \\
\text { students } \\
\text { (grades 1-5) }\end{array}$ & $\begin{array}{c}\text { Percent of } \\
\text { enrolled } \\
\text { students with } \\
\text { teacher } \\
\text { absent }\end{array}$ \\
\hline \multicolumn{5}{|l|}{ All students } \\
\hline Government girls' schools & $\begin{array}{c}1,715 \\
(13)\end{array}$ & 23.6 & $\begin{array}{c}2,237 \\
(19)\end{array}$ & 15.1 \\
\hline Government boys' schools & $\begin{array}{c}3,975 \\
(21)\end{array}$ & 17.0 & $\begin{array}{l}5,092 \\
(29)\end{array}$ & 10.5 \\
\hline Private schools & $\begin{array}{l}1,450 \\
(11)\end{array}$ & 9.9 & $\begin{array}{c}5,777 \\
(46)\end{array}$ & 8.4 \\
\hline Total & $\begin{array}{c}7,140 \\
(45)\end{array}$ & 17.2 & $\begin{array}{c}13,106 \\
(94)\end{array}$ & 10.4 \\
\hline \multicolumn{5}{|l|}{ Boys } \\
\hline Government girls' schools & 83 & 36.3 & 86 & 7.8 \\
\hline Government boys' schools & 3,458 & 18.0 & 4,332 & 10.5 \\
\hline Private schools & 928 & 10.6 & 3,769 & 8.3 \\
\hline Total & 4,469 & 20.4 & 8,187 & 9.0 \\
\hline \multicolumn{5}{|l|}{ Girls } \\
\hline Government girls' schools & 1,632 & 23.8 & 2,151 & 15.2 \\
\hline Government boys' schools & 517 & 16.1 & 760 & 2.6 \\
\hline Private schools & 522 & 8.5 & 2,008 & 9.2 \\
\hline Total & 2,671 & 16.6 & 4,919 & 9.4 \\
\hline
\end{tabular}


Table 6 Number of primary school classes taught, available teachers, teacher to class ratio, and student to teacher ratios (means)

\begin{tabular}{|c|c|c|c|c|c|c|c|}
\hline Indicator & $\begin{array}{c}\text { Number } \\
\text { of classes } \\
\text { (1) }\end{array}$ & $\begin{array}{c}\text { Number } \\
\text { of } \\
\text { teachers } \\
(2)\end{array}$ & $\begin{array}{c}\text { Number } \\
\text { of } \\
\text { teachers } \\
\text { present } \\
(3) \\
\end{array}$ & $\begin{array}{c}\text { Ratio of } \\
\text { teachers/ } \\
\text { classes } \\
(2 / 1)\end{array}$ & $\begin{array}{c}\text { Ratio of } \\
\text { teachers } \\
\text { present/ } \\
\text { classes } \\
(3 / 1)\end{array}$ & $\begin{array}{c}\text { Ratio of } \\
\text { students/ } \\
\text { teacher }\end{array}$ & $\begin{array}{r}\text { Ratio of } \\
\text { students } \\
\text { teachers } \\
\text { present }\end{array}$ \\
\hline & \multicolumn{7}{|c|}{1997} \\
\hline $\begin{array}{l}\text { Government } \\
\text { girls' schools }\end{array}$ & $\begin{array}{c}4.87 \\
(.335)\end{array}$ & $\begin{array}{c}4.71 \\
(1.74)\end{array}$ & $\begin{array}{c}2.80 \\
(1.38)\end{array}$ & $\begin{array}{l}.79 \\
(.35)\end{array}$ & $\begin{array}{l}.52 \\
(.27)\end{array}$ & $\begin{array}{l}28.3 \\
(17.0)\end{array}$ & $\begin{array}{l}42.3 \\
(21.0)\end{array}$ \\
\hline $\begin{array}{l}\text { Government } \\
\text { boys' schools }\end{array}$ & $\begin{array}{c}4.93 \\
(.426)\end{array}$ & $\begin{array}{c}4.42 \\
(2.26)\end{array}$ & $\begin{array}{l}3.75 \\
(1.94)\end{array}$ & $\begin{array}{l}.79 \\
(.37)\end{array}$ & $\begin{array}{l}.65 \\
(.38)\end{array}$ & $\begin{array}{l}27.1 \\
(8.9)\end{array}$ & $\begin{array}{c}35.3 \\
(14.0)\end{array}$ \\
\hline Private & $\begin{array}{c}4.84 \\
(.361)\end{array}$ & $\begin{array}{c}4.63 \\
(1.21)\end{array}$ & $\begin{array}{c}4.46 \\
(1.44)\end{array}$ & $\begin{array}{l}.88 \\
(.25)\end{array}$ & $\begin{array}{c}.83 \\
(.31)\end{array}$ & $\begin{array}{l}22.7 \\
(4.5)\end{array}$ & $\begin{array}{l}26.0 \\
(8.2)\end{array}$ \\
\hline \multirow[t]{2}{*}{ Total } & $\begin{array}{c}4.9 \\
(.40)\end{array}$ & $\begin{array}{c}4.6 \\
(1.6)\end{array}$ & $\begin{array}{c}3.7 \\
(1.76)\end{array}$ & $\begin{array}{l}.81 \\
(.34)\end{array}$ & $\begin{array}{l}.65 \\
(.35)\end{array}$ & $\begin{array}{c}26.4 \\
(11.3)\end{array}$ & $\begin{array}{c}35.1 \\
(16.3)\end{array}$ \\
\hline & \multicolumn{7}{|c|}{2004} \\
\hline $\begin{array}{l}\text { Government } \\
\text { girls' schools }\end{array}$ & $\begin{array}{c}5.2 \\
(.553)\end{array}$ & $\begin{array}{c}4.98 \\
(1.76)\end{array}$ & $\begin{array}{c}3.94 \\
(1.41)\end{array}$ & $\begin{array}{l}.78 \\
(.33)\end{array}$ & $\begin{array}{c}.64 \\
(.28)\end{array}$ & $\begin{array}{c}26.4 \\
(11.0)\end{array}$ & $\begin{array}{l}35.6 \\
(21.5)\end{array}$ \\
\hline $\begin{array}{l}\text { Government } \\
\text { boys' schools }\end{array}$ & $\begin{array}{c}5.9 \\
(1.9)\end{array}$ & $\begin{array}{c}6.73 \\
(3.46)\end{array}$ & $\begin{array}{l}6.13 \\
(3.5)\end{array}$ & $\begin{array}{l}.82 \\
(.42)\end{array}$ & $\begin{array}{l}.74 \\
(.42)\end{array}$ & $\begin{array}{c}31.2 \\
(14.0)\end{array}$ & $\begin{array}{c}34.5 \\
(13.6)\end{array}$ \\
\hline Private & $\begin{array}{c}5.6 \\
(1.7)\end{array}$ & $\begin{array}{c}6.77 \\
(3.28)\end{array}$ & $\begin{array}{l}6.45 \\
(3.4)\end{array}$ & $\begin{array}{l}1.06 \\
(.40)\end{array}$ & $\begin{array}{l}1.0 \\
(.44)\end{array}$ & $\begin{array}{l}20.3 \\
(9.6)\end{array}$ & $\begin{array}{l}23.6 \\
(16.0)\end{array}$ \\
\hline Total & $\begin{array}{c}5.6 \\
(1.6)\end{array}$ & $\begin{array}{l}6.42 \\
(3.3)\end{array}$ & $\begin{array}{c}5.9 \\
(3.3)\end{array}$ & $\begin{array}{l}.94 \\
(.41)\end{array}$ & $\begin{array}{l}.85 \\
(.43)\end{array}$ & $\begin{array}{c}25.0 \\
(12.4)\end{array}$ & $\begin{array}{c}29.5 \\
(17.4)\end{array}$ \\
\hline
\end{tabular}

Note: Standard deviations in parentheses. Table is for grades 1-5. We do not include pre-school or nursery school classes as they are not a required part of the primary school curriculum. 
Appendix Table A Number of teachers per school type and survey round

$1997 \quad 2004$

Total

School type

Government

$187 \quad 244 \quad 431$

Private

$92 \quad 285 \quad 377$

NGO

$0 \quad 53 \quad 53$

Total

$279 \quad 582 \quad 861$

Type of government school

Girls'

$121 \quad 159 \quad 280$

Boys'

$\begin{array}{lll}66 & 85 & 151\end{array}$

Mixed

$92 \quad 338 \quad 431$

Total

$279 \quad 582 \quad 861$




\section{Poverty, Gender, and Youth Working Papers}

If still in print, single copies of up to three working papers from 1989 through 2003 are available free of charge.

Beginning with the 2004 issues, working papers are no longer available in print format. Instead they are distributed electronically. As each new paper is completed, subscribers are notified by e-mail and a link to the paper is provided.

To subscribe to the Poverty, Gender, and Youth working paper e-mail notification list, or to obtain back issues from 1989 to 2003, please send your request to pgywp@popcouncil.org.

PDFs of recent issues are available at www.popcouncil.org/publications/wp/index.html

2007

1 Sharon Ghuman and Cynthia B. Lloyd, "Teacher absence as a factor in gender inequalities in access to primary schooling in rural Pakistan."

Policy Research Division working papers

2006

219 Cynthia B. Lloyd and Barbara S. Mensch, "Marriage and childbirth as factors in school exit: An analysis of DHS data from sub-Saharan Africa."

218 Ayaga A. Bawah, James F. Phillips, Martin Adjuik, Maya VaughanSmith, Bruce MacLeod, and Fred N. Binka, "The impact of immunization on the association between poverty and child survival: Evidence from Kassena-Nankana District of northern Ghana."

217 Zachary Zimmer, "Poverty, wealth inequality, and health among older adults in rural Cambodia."

216 John Bongaarts, "Late marriage and the HIV epidemic in sub-Saharan Africa."
215 John Bongaarts, "How long will we live?"

214 Zachary Zimmer, Toshiko Kaneda, and Laura Spess, "Urban versus rural mortality among older adults in China."

213 Paul Demeny and Geoffrey McNicoll, "The political demography of the world system, 2000-2050."

212 Monica Grant and Kelly Hallman, "Pregnancy-related school dropout and prior school performance in South Africa."

211 Kelly Hallman, Sara Peracca, Jennifer Catino, and Marta Julia Ruiz, "Multiple disadvantages of Mayan females: The effect of gender, ethnicity, poverty, and residence on education in Guatemala."

210 Geoffrey McNicoll, "Policy lessons of the East Asian demographic transition."

209 Cynthia B. Lloyd, Cem Mete, and Monica J. Grant, "The implications of changing educational and family circumstances for children's grade progression in rural Pakistan: 19972004." 
Mian Bazle Hossain, James F.

208 James F. Phillips, Ayaga A. Bawah, and Fred N. Binka, "Accelerating reproductive and child health program development: The Navrongo

Initiative in Ghana."

Phillips, and Thomas K. LeGrand, "The impact of childhood mortality on fertility in six rural thanas of Bangladesh."

197 Kristine R. Baker, Mary Beth Ofstedal, Zachary Zimmer, Zhe Tang, and Yi-Li Chuang, "Reciprocal effects of health and economic wellbeing among older adults in Taiwan and Beijing."

206 Barbara S. Mensch, Monica J. Grant, and Ann K. Blanc, "The changing context of sexual initiation in subSaharan Africa."

196 Mark R. Montgomery and Paul C. Hewett, "Poverty and children's schooling in urban and rural

205 Geoffrey McNicoll, "Population and Senegal." sustainability."

204 John Bongaarts, "The causes of stalling fertility transitions."

203 Ayaga A. Bawah and Fred N. Binka, "How many years of life could be saved if malaria were eliminated from a hyperendemic area of northern Ghana?"

202 Barbara S. Mensch, Susheela Singh, and John B. Casterline, "Trends in the timing of first marriage among men and women in the developing world."

201 Zachary Zimmer, “Active life expectancy and functional limitations among older Cambodians: Results from a 2004 survey."

200 Brian Wells Pence, Philomena Nyarko, James F. Phillips, and Cornelius Debpuur, "The effect of community nurses and health volunteers on child mortality: The Navrongo Community Health and Family Planning Project.”

199 Zachary Zimmer, Linda G. Martin, Mary Beth Ofstedal, and Yi-Li Chuang, "Education of adult children and mortality of their elderly parents in Taiwan." 